\title{
Extract of Synedrella nodiflora (L) Gaertn exhibits antipsychotic properties in murine models of psychosis
}

Patrick Amoateng $^{1 *}$ D, Samuel Adjei ${ }^{2}$, Dorcas Osei-safo ${ }^{3}$, Kennedy K. E. Kukuia', Emelia Oppong Bekoe ${ }^{4}$, Thomas K. Karikari, ${ }^{5,6}$ and Samuel B. Kombian ${ }^{7}$

\begin{abstract}
Background: The hydro-ethanolic whole plant extract of Synedrella nodiflora (SNE) has demonstrated anticonvulsant, sedative and analgesic effects. Preliminary studies conducted in animals, SNE significantly decreased stereotypic behaviours suggesting antipsychotic potential. Coupled with the central nervous system depressant effects of SNE, we hypothesized that it may have utility in the management of psychosis. The present study therefore investigated the antipsychotic potential of the SNE in several murine models of psychosis.

Method: The primary central nervous system activities of SNE (30-3000 mg/kg, p.o) were investigated using the Irwin's test. The novelty-induced rearing, locomotion and stereotypy counts provoked by SNE (100-1000 mg/kg, p.o) were conducted using the open-field paradigm. The antipsychotic test models used in the screening of SNE $(100-1000 \mathrm{mg} / \mathrm{kg}$, p.o) included apomorphine-induced stereotypy, rearing, locomotion and cage climbing activities. The combined effects of a low dose of SNE $(100 \mathrm{mg} / \mathrm{kg})$ with various doses of haloperidol and chlorpromazine were analysed using the apomorphine-induced cage climbing and stereotypy, respectively. The ability of SNE to cause catalepsy in naïve mice as well as its effect on haloperidol-induced catalepsy was assessed.

Results: SNE showed acetylcholine-like and serotonin-like activities in the Irwin test, with sedation occurring at high doses. SNE significantly reduced the frequencies of novelty- and apomorphine-induced rearing and locomotion; stereotypy behaviour and the frequency and duration of apomorphine-induced cage climbing in mice. In all the tests performed, SNE was less potent than the reference drugs used (chlorpromazine and haloperidol). In addition, SNE potentiated the effects of haloperidol and chlorpromazine on apomorphine-induced cage climbing and stereotypy activities in mice.
\end{abstract}

Conclusion: SNE, while exhibiting antipsychotic properties itself, can also potentiate the antipsychotic effects of chlorpromazine and haloperidol.

Keywords: Synedrella nodiflora, chlorpromazine, haloperidol, apomorphine, stereotypy, antipsychotic

\section{Key message}

An extract of Synedrella nodiflora possesses antipsychotic properties

\section{Background}

Psychosis, a major public health concern, is a chronic recurrent neuropsychiatric disorder that adversely impacts

\footnotetext{
* Correspondence: pamoateng@ug.edu.gh

${ }^{1}$ Department of Pharmacology and Toxicology, School of Pharmacy, College of Health Sciences, University of Ghana, P.O Box LG 43, Legon, Accra, Ghana Full list of author information is available at the end of the article
}

the quality of life of the sufferers [1]. An estimated $2 \%$ of people worldwide experience an episode of psychosis in their lifetime, with $80 \%$ of these people experiencing the episodes between the ages of 16 and 40 years $[2,3]$. Although the aetiology of the disease is unknown, hyperdopaminergic activity is closely linked with the pathogenesis of psychosis [4]. Individuals with psychoses are more prone to suicide, depression, anxiety, aggression, substance abuse, cognitive impairment, victimisation, poverty and increased medical problems [5]. The onset of psychosis is determined by an underlying vulnerability 
coupled with the impact of environmental stress (including drug/substance abuse), which may trigger active psychotic symptoms, and this provides a basis for the stress/vulnerability model of psychosis [6].

Current antipsychotic drugs only provide symptomatic relief, without altering disease progression [7, 8]. Additionally, the clinical efficacy of these drugs is often limited by adverse reactions such as photo-sensitivity, jaundice, disabling seizures, blindness, agranulocytosis and neuroleptic malignant syndrome $[9,10]$. Moreover, the overall functional and quality of life outcomes of patients still remain poor after treatment [5]. Thus, there is a critical need to search for more effective and less toxic therapeutic agents to manage psychosis. An increasing number of herbal products have been introduced into psychiatric practice as alternative or complementary medicines, following the identification of their therapeutic potential and mechanisms of action [11].

Synedrella nodiflora (L.) Gaertn (family Asteraceae) is a common shrub found mainly around small rivers and streams as well as along roadsides and under shady trees [12]. In Ghana, traditional medicine practitioners use the aqueous extract obtained after boiling the whole plant for the management of epilepsy and pain. The leaves are also used medicinally to prevent spontaneous abortion, hiccup, as a laxative and feed for livestock [12]. The hydroethanolic extract of the whole plant has demonstrated anticonvulsant [13], sedative [14], in vitro antioxidant and free radical scavenging properties [15] as well as antinociceptive properties in acute and neuropathic pain [16, 17]. An acute, sub-acute and sub-chronic toxicity of the extract in rodents showed no significant changes in haematological, biochemical and organ histological changes of animals treated with an $\mathrm{LD}_{50}$ greater than $6400 \mathrm{mg} / \mathrm{kg}$ [18-20]. Our preliminary work conducted on this extract revealed that it was able to reduce stereotypic behaviour characteristic of schizophrenia and other psychotic conditions in experimental animals suggesting that it may have utility in the management of psychotic conditions [21]. Thus, the present study sought to examine, in greater detail, if SNE possessed anti-psychotic potential and if so, how it compared with current clinically available drugs using in vivo models of psychosis in mice.

\section{Methods}

\section{Plant collection and extraction}

Samples of the plant were collected from the Botanical Gardens, University of Ghana, Accra (N5 ${ }^{0} 3932.067$ W0 ${ }^{0} 11$ 55.247) in August 2012 and were identified and authenticated at Ghana Herbarium, Department of Botany, University of Ghana, Legon, Accra where a voucher specimen (PA01/UGSOP/GH12) was kept. The hydro-ethanolic extract was prepared as previously described [13, 22]. Briefly, samples of the collected plant were air-dried for 7 days and powdered. Two kilograms of the powder were cold-macerated with $70 \% \mathrm{v} / \mathrm{v}$ of ethanol in water. The hydro-ethanolic extract was then evaporated using a rotary evaporator (Buchi Rotavapor R-300, Flawil, Switzerland) under reduced pressure to remove ethanol. The aqueous portion was frozen at $-20{ }^{\circ} \mathrm{C}$ and lyophilised (Bench-top Freeze Dryer, Labfreez Instruments Co., Ltd., Beijing, China). A $14 \%$ percentage yield of dried extract was obtained, labelled as SNE and kept in a dessicator.

\section{Qualitative phytochemistry of SNE}

The extract (SNE) was screened for the presence of phytochemical constituents such as alkaloids, glycosides, tannins, sterols, flavonoids using determination protocols as previously described [23] and reported [13].

\section{High performance liquid chromatography (HPLC) of SNE}

HPLC analysis was performed on a Perkin Elmer Flexar HPLC, fitted with a PDA detector and a manual injector. The constituents of SNE were separated on a $\mu$ Bondapak C18 Column $(150 \times 4.6 \mathrm{~mm}, 3 \mu \mathrm{m})$ with mobile phase $0.1 \%$ formic acid (A) and Methanol (A). Gradient elution started with $100 \%$ A for $10 \mathrm{~min}$ and then moved to $50 \%$ in $40 \mathrm{~min}$. It was kept at $50 \%$ for another $10 \mathrm{~min}$ and returned to $100 \%$ in 2 min, making a total run time of $62 \mathrm{~min}$. The flow rate was $1 \mathrm{~mL} / \mathrm{min}$ and the sample injection was 100 $\mathrm{uL}\left(0.108 \mathrm{~g}\right.$ in $1: 4$ methanol- $\mathrm{H}_{2} \mathrm{O}$ mixture). The wavelength was set at $315 \mathrm{~nm}$.

\section{Experimental animals and housing}

Female Imprint Control Region (ICR) mice 6-8 weeks old(weight: 20-30 g), were obtained from and maintained at the Department of Animal Experimentation, Noguchi Memorial Institute for Medical Research (NMIMR), University of Ghana, Legon, Accra, where most of the behavioural experiments were performed. The animals were housed in groups of five in stainless steel cages (dimensions: $34 \mathrm{~cm} \times 47 \mathrm{~cm} \times 18 \mathrm{~cm}$ ) with soft wood shavings as bedding and maintained under laboratory conditions (temperature $22 \pm 2{ }^{\circ} \mathrm{C}$, relative humidity $60-70 \%$, and $12 \mathrm{~h}$ light-dark cycle). Additionally, the animals were fed with normal commercial pellet diet (AGRIMAT, Kumasi), and given water ad libitum.

In other experiments conducted at the Health Science Center (HSC), Kuwait University, female Balb/c mice (20$30 \mathrm{~g}$ ) were obtained from and maintained at the Animal Resource Center, HSC, Kuwait University, Kuwait. Similar laboratory conditions as described above were maintained for this set of animals. All experiments were performed during the day between the hours of 8:00-15:00 GMT and complied with internationally recognized and accepted guidelines for the humane handling of experimental animals as contained in those published by the Canadian Council on Animal Care, 1993. 


\section{Chemicals and reagents}

The following compounds (source/manufacturer) were used in this study: Chlorpromazine hydrochloride (Renandin, France), haloperidol (STEROP, Belgium) and Apomorphine hydrochloride (Macfarlan Smith Ltd., Scotland, UK).

\section{Primary observation test}

The behavioural and neuroactive effects of SNE were initially evaluated according to standardised observation grid similar to that previously described [24]. Briefly, groups of mice $(n=5)$ were treated with $\operatorname{SNE}(30,100,300,1000$ or $3000 \mathrm{mg} / \mathrm{kg}$, p.o) or vehicle (distilled water, $10 \mathrm{ml} / \mathrm{kg}$, p.o). Observations were performed 15, 30, 60, 120 and $180 \mathrm{~min}$ after administration of the test substance and also $24 \mathrm{~h}$ later and behavioural modifications, physiologic and neurotoxic symptoms were recorded according to a standardised observation grid derived from Irwin (1968). The grid contained the following parameters: death, convulsions, tremor, Straub tail, sedation, excitation, jumping, abnormal gait (rolling, tiptoe), motor incoordination, altered muscle tone, loss of grasping, akinesia, catalepsy, loss of traction, loss of balance, fore-paw treading, writhing, piloerection, stereotypies (sniffing, chewing, head movements), headtwitches, scratching, altered respiration, aggression, altered fear, altered reactivity to touch, ptosis, exophthalmia, loss of righting reflex, loss of corneal reflex, analgesia, defecation/ diarrhoea, salivation, lacrimation, and pupil diameter (myosis/mydriasis).

\section{Assessment of novelty-induced rearing and locomotor behaviour}

The novelty-induced behaviour was evaluated using an open-field observation box (dimensions: $25 \mathrm{~cm} \times 25 \mathrm{~cm} \times 30 \mathrm{~cm}$ ) made of transparent Perspex and behavioural events recorded using a camcorder and tracked with Behavior Tracker ${ }^{\circ}$ software. The base of the maze had 16 squares $(6.5 \mathrm{~cm} \times 6.5 \mathrm{~cm})$ demarcated with a non-toxic permanent marker.

To conduct this investigation, groups of mice were treated with SNE $(100,300,1000 \mathrm{mg} / \mathrm{kg}$, p.o) or chlorpromazine $1 \mathrm{mg} / \mathrm{kg}$ (i.p) or vehicle (distilled water, $10 \mathrm{ml} / \mathrm{kg}$, p.o). Thirty minutes after the treatments, the animals were placed individually into the open-field observational box and their behaviour recorded for $5 \mathrm{~min}$ using a camcorder (Everio ${ }^{\text {tw }}$ model, GZ-MG 130 U, JVC, Tokyo, Japan) suspended above the maze with the aid of a stand. Novelty-induced rearing was counted as the number of times the mouse stood on its hind limbs with its forelimbs against the wall of the observation cage (supported rearing) or in free air (unsupported rearing). The number of rearing (both supported and unsupported) was tracked for $5 \mathrm{~min}$. Also, the number of line crossing was counted as a representation of locomotor activity.

\section{Novelty-induced stereotypy}

The number and total duration of stereotypic behaviour exhibited by the mice pre-treated with SNE $(10,100$ or $1000 \mathrm{mg} / \mathrm{kg}$, p.o) or vehicle (distilled water, $10 \mathrm{ml} / \mathrm{kg}$, p.o) over two-hour periods was assessed in an automated open-field test (VersaMax Animal Activity Monitoring System, AccuScan Instrument Inc., USA) as previously reported [14]. This test system comprised four animal monitoring chambers (16 in $\times 16$ in $\times 12$ in) covered by transparent lids with perforations, an analyser and a computer. The base of each monitoring chamber was lined with vertical and horizontal laser generators and sensors. The behaviours of interest were pre-configured into the system. During the test, any behaviour exhibited by the test animals through beam interruptions were transmitted to the analyser, recorded on a computer, and the data subsequently exported to Microsoft Excel. Our experimental setup enabled the researcher to test the same animal under three different experimental conditions (primary, secondary and auxillary in succession). In the experiments, primary and secondary sessions were conducted for 60 and $120 \mathrm{~min}$ respectively. The test animals were made to acclimatise by undergoing a two-day procedure in the system without drug administration. On the third day, after an initial 60 min primary session, the mice were treated with SNE or distilled water (as a control) and tested for a $120 \mathrm{~min}$ secondary session. When the animal broke the same beam (or set of beams) repeatedly then the monitor considered the animal as exhibiting stereotypy. This typically happened during grooming, head bobbing, sniffing, gnawing, etc.

\section{Apomorphine-induced locomotor and rearing activity}

Using the experimental set-up as described in the noveltyinduced locomotor and rearing activities, mice were pretreated with $\operatorname{SNE}(100,300$ or $1000 \mathrm{mg} / \mathrm{kg}$, p.o) or chlorpromazine $(0.1,0.3$, or $1.0 \mathrm{mg} / \mathrm{kg}$, i.p) or vehicle (distilled water, $10 \mathrm{ml} / \mathrm{kg}, p . o$ ) and $30 \mathrm{~min}$ later, they received apomorphine $(2 \mathrm{mg} / \mathrm{kg}$, i.p) and placed in the open field test chamber. A vehicle group without apomorphine administration was also included. The events were recorded with a camcorder for $30 \mathrm{~min}$ and the videos tracked for the frequency of rearing and line-crossings.

\section{Apomorphine-induced stereotypy}

This procedure was performed as previously described [25]. Briefly, mice were pre-treated with various doses of the extracts $(10,100,1000 \mathrm{mg} / \mathrm{kg}$, p.o), chlorpromazine (0.1, 0.3, and $1 \mathrm{mg} / \mathrm{kg}$, i.p) or vehicle $(10 \mathrm{ml} / \mathrm{kg}$, p.o). Thirty minutes later, apomorphine $(2 \mathrm{mg} / \mathrm{kg}$, i.p) was administered to each mouse and placed into an observation cage and events recorded for $30 \mathrm{~min}$. The frequency of stereotypic behaviour, mainly sniffing and gnawing, were tracked and scored. The stereotypic episodes were scored 
as follows: absence of stereotypy (0), sniffing (1), gnawing (2) and staying on the same spot (3). The frequency of these behaviours were measured and weighted as a product of the frequency and the behaviour score. A total of all the scores were made for each mouse and a mean of 5 min period calculated and plotted as described [26]. An antagonism of the classic stereotypic behaviours of a low dose of apomorphine indicated neuroleptic (antipsychotic) activity.

In a separate experiment, combination of a dose of SNE lower than its anti-psychotic $\mathrm{ED}_{50}$ dose (i.e SNE $100 \mathrm{mg} / \mathrm{kg}$, p.o) with three doses of chlorpromazine $(0.1,0.3$ and $1.0 \mathrm{mg} / \mathrm{kg}$, i.p) were evaluated using the fixed ratio method [27] for synergism, addition or antagonism. The effect of the combinations of SNE and chlorpromazine was assessed for antipsychotic effects using the apomorphine-induced stereotypy test as described above.

\section{Apomorphine-induced cage climbing}

This method as described previously [28] was employed with minor modifications. Briefly, mice were treated with SNE (100, 300, $1000 \mathrm{mg} / \mathrm{kg}$, p.o), haloperidol (0.1, 0.3, $1 \mathrm{mg} / \mathrm{kg}$, i.p) or vehicle (distilled water, $10 \mathrm{ml} / \mathrm{kg}, \mathrm{p} . \mathrm{o}$ ) and injected with apomorphine $(2 \mathrm{mg} / \mathrm{kg}$, i.p) $30 \mathrm{~min}$ later and immediately placed individually into an all wire-meshed cage (mesh size: $1 \mathrm{~cm} \times 1 \mathrm{~cm}$; dimensions $=27 \mathrm{~cm} \times 20 \mathrm{~cm} \times 20 \mathrm{~cm})$. A camcorder placed above the cage was used to record animal behaviour in the cage for $30 \mathrm{~min}$ post-apomorphine injection and the video recording tracked the frequency and duration of climbing. In a preliminary study done in our laboratory, haloperidol was found to be more potent than chlorpromazine in reducing the frequency and duration of cage climbing, thus in this assay haloperidol was used as the reference antipsychotic drug.

In a separate experiment using the above experimental protocol, a combination of low dose SNE (100 mg/kg, p.o) and three doses of haloperidol (0.1, 0.3 and $1.0 \mathrm{mg} / \mathrm{kg}$, i.p) were evaluated for synergism, addition or antagonism using the fixed ratio method [27].

\section{Extract/drug-induced catalepsy}

The ability of SNE to induce catalepsy in mice was evaluated as previously described $[29,30]$. Briefly, mice treated with the SNE $(100,300,1000 \mathrm{mg} / \mathrm{kg}$, p.o), haloperidol $(0.1,0.31 .0 \mathrm{mg} / \mathrm{kg}$, i.p) or vehicle were tested individually on the catalepsy set-up made of a Perspex rod elevated over a height of $3.5 \mathrm{~cm} .30$ min posttreatment, the mice were placed individually on the rod with their fore-paws and time spent by each mouse in that position recorded until the animal removed its forepaws from the rod unto the floor or climbed the rod, indicating the end of catalepsy. This procedure was repeated at 30, 60 and 120 min post-treatment.

\section{Haloperidol-induced catalepsy}

The effect of SNE on haloperidol-induced catalepsy was performed as previously described with a slight modification [30, 31]. In brief, mice were pre-treated with SNE (100, 300 or $1000 \mathrm{mg} / \mathrm{kg}$, p.o) or vehicle (distilled water, $0.01 \mathrm{ml} / \mathrm{kg}, \mathrm{p} . \mathrm{o})$ and $30 \mathrm{~min}$ later each mouse was treated with haloperidol $1 \mathrm{mg} / \mathrm{kg}$ (i.p) and tested for catalepsy as described above.

\section{Statistical analysis}

The $\mathrm{ED}_{50}$ (concentration responsible for $50 \%$ of the maximal effect) of extract/reference drug was determined using an iterative computer least squares method in Prism for Windows version 5.0 (GraphPad Software, San Diego, CA, USA) with the following nonlinear regression (four-parameter logistic equation).

$$
Y=\frac{a+(a-b)}{\left.1+10^{\left(\left(\log E D_{50}-X\right) \times \text { Hill Slope }\right)}\right)}
$$

Where, $\mathrm{X}$ is the logarithm of concentration. $\mathrm{Y}$ is the response, starting at $\boldsymbol{a}$ and ending at point $\boldsymbol{b}$ with a sigmoid shape.

The fitted midpoints $\left(\mathrm{ED}_{50} \mathrm{~s}\right)$ of the curves were compared statistically using the $F$ test.

Statistical analyses (one- or two-way ANOVA followed by an appropriate post hoc test) were conducted using Prism 5.0, with $P \leq 0.05$ considered statistically significant. Graphs were plotted using Sigma Plot for Windows version 11.0 (Systat Software Inc., Germany).

\section{Results}

\section{Qualitative phytochemistry of SNE}

SNE was found to contain flavonoids, tannins, saponins, alkaloids, cardiac glycosides, coumarins, triterpenes, sterols, anthraquinones and phenolic compounds as previously reported [13].

\section{High performance liquid chromatography (HPLC) of SNE} Figure 1 shows the HPLC chromatogram of SNE. Two major constituents were observed at retention times 42.56 and $46.51 \mathrm{~min}$. The percentage composition of these constituents was determined to be $45.72 \%$ and $36.88 \%$ respectively, using the areas under the curve (AUCs).

\section{Primary observation test}

SNE-treated mice primarily showed defaecation and fore-paw treading at all doses $30-3000 \mathrm{mg} / \mathrm{kg}$ with sedation. There were no convulsion, ptosis, motor incoordination, stereotypic behaviour or death in the animals pre-treated with the extract at the $0-180 \mathrm{~min}$ and $24 \mathrm{~h}$ observational period. 


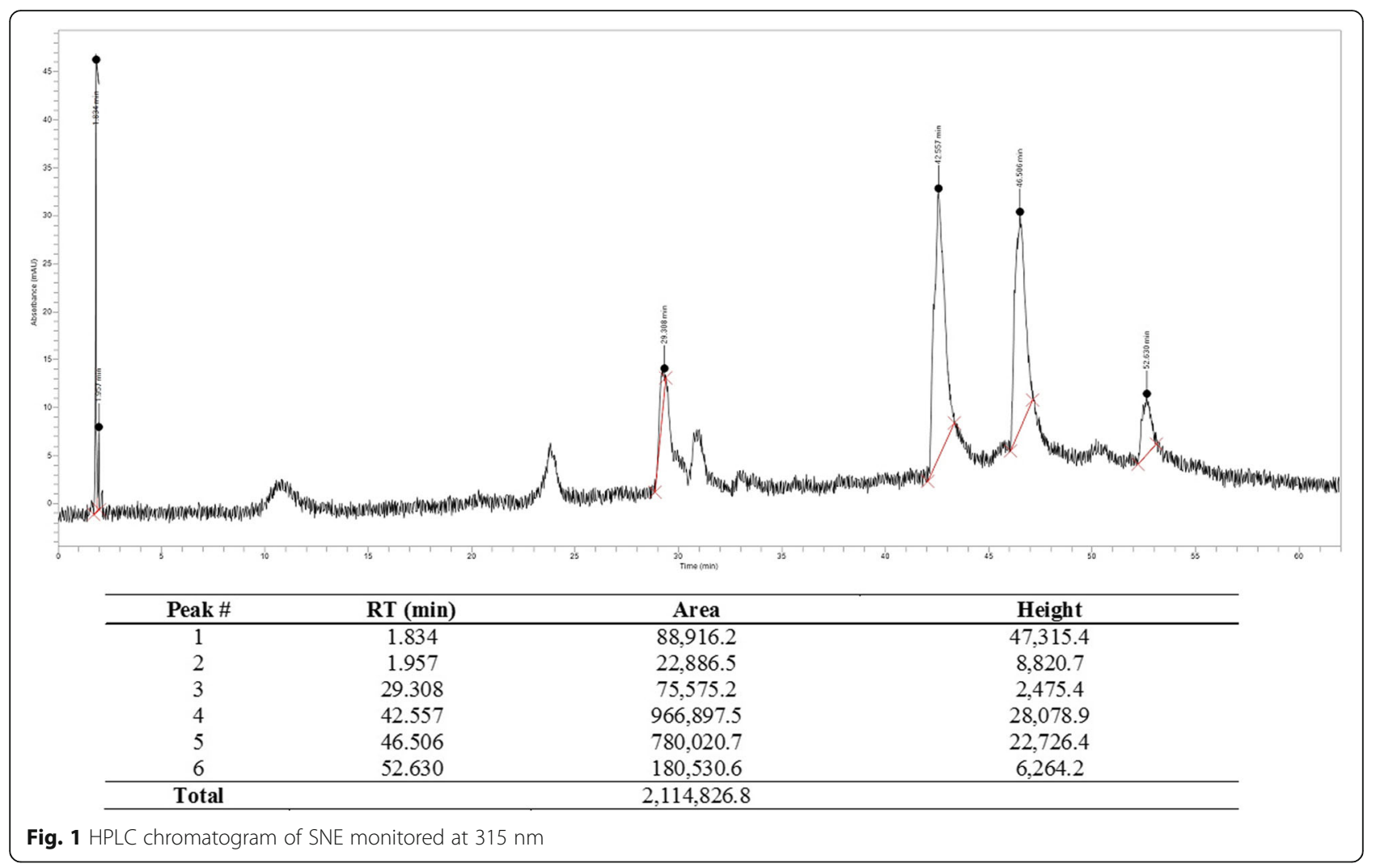

\section{Assessment of novelty-induced rearing and locomotor behaviour}

There was a significant decrease in the frequencies of rearing $\left(P<0.0001, \mathrm{~F}_{4,16}=25.83\right.$, Fig. 1) and linecrossing $\left(P=0.0001, \mathrm{~F}_{3,15}=14.62\right.$, Fig. 1$)$ behaviours in the SNE-treated and chlorpromazine $(1 \mathrm{mg} / \mathrm{kg})$-treated mice in comparison with the vehicle-treated group. The percentage decrease in the frequencies of rearing and line-crossing for $\operatorname{SNE}(100,300$ and $1000 \mathrm{mg} / \mathrm{kg})$ and CPZ (1 mg/kg) were $0 \%, 32 \%, 3 \%$ and $77 \%$ respectively [rearing] and 42\%, 50\%, 36\% and 70\% respectively [linecrossing]. The decreased effects in the SNE-treated mice were not dose-dependent (Fig. 1).

\section{Apomorphine-induced locomotor and rearing activity}

Apomorphine induced a characteristic increase in rearing and locomotor activity in the treated group when compared with mice treated with the vehicle (i.e no apomorphine) (Fig. 2a and d). Pretreatment of mice with SNE resulted in a significant reduction in the frequency of apomorphine-induced rearing behaviour $\left(P=0.0011, F_{3,15}=9.103\right.$, Fig. 2b) and linecrossing (an indicator of locomotor activity; $P=0.0013, \mathrm{~F}_{3,12}=10.12$, Fig. 2e). The percentage of reductions in rearing activity by $\operatorname{SNE~(100,300,~}$ $1000 \mathrm{mg} / \mathrm{kg}$ ) were $68 \%, 58 \%$ and $61 \%$ respectively and those for line-crossing were $60 \%, 70 \%$ and $49 \%$ respectively. Likewise, chlorpromazine significantly reduced apomorphine-induced rearing $(P=0.0065$, $\mathrm{F}_{3,15}=6.067$, Fig. 2c) and locomotor activity $\left(P=0.007, F_{3,12}=6.58\right.$, Fig. $\left.2 f\right)$ in mice that were pretreated with it. The percentage of reductions in rearing activity by $\mathrm{CPZ}(0.1,0.3,1.0 \mathrm{mg} / \mathrm{kg})$ were $31 \%, 50 \%$ and $75 \%$ respectively and those for linecrossing were $35 \%, 42 \%$ and $28 \%$ respectively.

\section{Novelty-induced stereotypy}

The frequency of stereotypy in the mice prior to being treated with SNE or vehicle were not significantly different from each other for the $60 \mathrm{~min}$ primary (no-drug) session (Fig. 3?). However, 10 min after the SNE administration, there was a significant drop $(77 \%$; $P<0.0001$, $\mathrm{F}_{3,68}=11.02$, Fig. 3a) in the frequency of stereotypy in the mice treated with SNE $1000 \mathrm{mg} / \mathrm{kg}$. This drop was $92 \%$ at $20 \mathrm{~min}$ post SNEand was sustained throughout the $120 \mathrm{~min}$ observation period. However, at the $100 \mathrm{mg} / \mathrm{kg}$ dose level $10 \mathrm{~min}$ post administration, the decrease in stereotypy count was $84 \%$ and lasted for only $60 \mathrm{~min}$ before returning nearly to the baseline by the 180th min. Finally, for the $10 \mathrm{mg} / \mathrm{kg}$ SNE-treated mice, stereotypy count declined by $56 \%$ at $30 \mathrm{~min}$ and recovered to baseline. The overall effect, as calculated from the AUC from the time-course curves for each dose of SNE, indicated a significant dose-dependent decrease in 

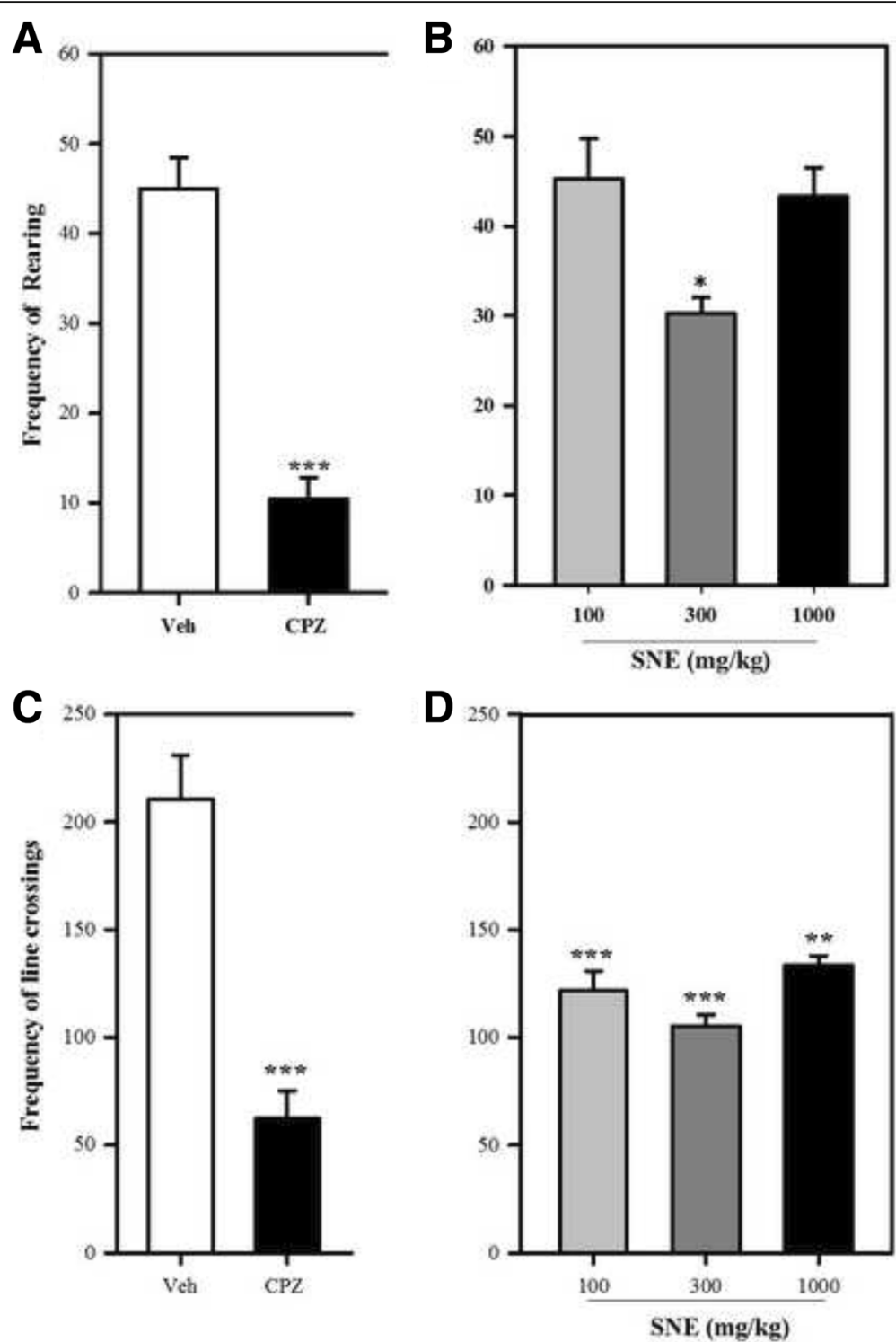

Fig. 2 Frequency of rearing ( $\mathbf{A}$ and $\mathbf{B}$ ) and line-crossings ( $\mathbf{C}$ and $\mathbf{D})$ of mice treated with chlorpromazine (CPZ; $1 \mathrm{mg} / \mathrm{kg}$, i.p), SNE and vehicle (Veh) when observed for $5 \mathrm{~min}$ in an open-field paradigm. Data are mean \pm SEM $(n=5)$. ${ }^{*} \leq \leq 0.05,{ }^{* *} P \leq 0.01,{ }^{* * *} P \leq 0.001$ compared with vehicle group (one-way ANOVA followed by a Dunnett's multiple comparison post hoc test)

the stereotypy count $\left(P=0.0002, \mathrm{~F}_{3,16}=12.10\right.$, Fig. $\left.2 \mathrm{~b}\right)$. A similar trend was observed when the total duration of stereotypy was measured (Fig. 2c \& d).

\section{Apomorphine-induced stereotypy}

Apomorphine-induced stereotypic behaviours in mice was characterised by sniffing and gnawing. SNE and CPZ significantly decreased the apomorphine-induced stereotypy scores in the treated mice (SNE: $P=0.0007, \mathrm{~F}_{3,14}=10.64$, Fig. 4b; CPZ: $P<0.0001, \mathrm{~F}_{3,16}=51.19$, Fig. 4c). The percentage decrease in the stereotypy scores by SNE 100, 300 and $1000 \mathrm{mg} / \mathrm{kg}$ were $20 \%, 49 \%$ and $64 \%$ respectively; and that for CPZ 0.1, 0.3 and $1.0 \mathrm{mg} / \mathrm{kg}$ were $50 \%, 66 \%$ and
$76 \%$, respectively. SNE was less potent than $\mathrm{CPZ}$ in this model (Fig. 5).

Interestingly, the antipsychotic effect of CPZ in combination with SNE $100 \mathrm{mg} / \mathrm{kg}$ was superior to that of CPZ alone (i.e 1.3 times more potent) (Fig. 6).

\section{Apomorphine-induced cage climbing}

Pretreatment with SNE (100, 300 and $1000 \mathrm{mg} / \mathrm{kg})$ significantly and dose-dependently reduced the total frequency of climbing $\left(P<0.0001, \mathrm{~F}_{3,16}=37.10\right.$; Fig. $\left.7 \mathrm{~b}\right)$ by $58 \%, 80 \%$ and $94 \%$ respectively. SNE (100, 300 and $1000 \mathrm{mg} / \mathrm{kg}$ ) also significantly and dose-dependently reduced the duration $\left(P<0.0001, \mathrm{~F}_{3,13}=30.31\right.$; Fig. 7e $)$ of 

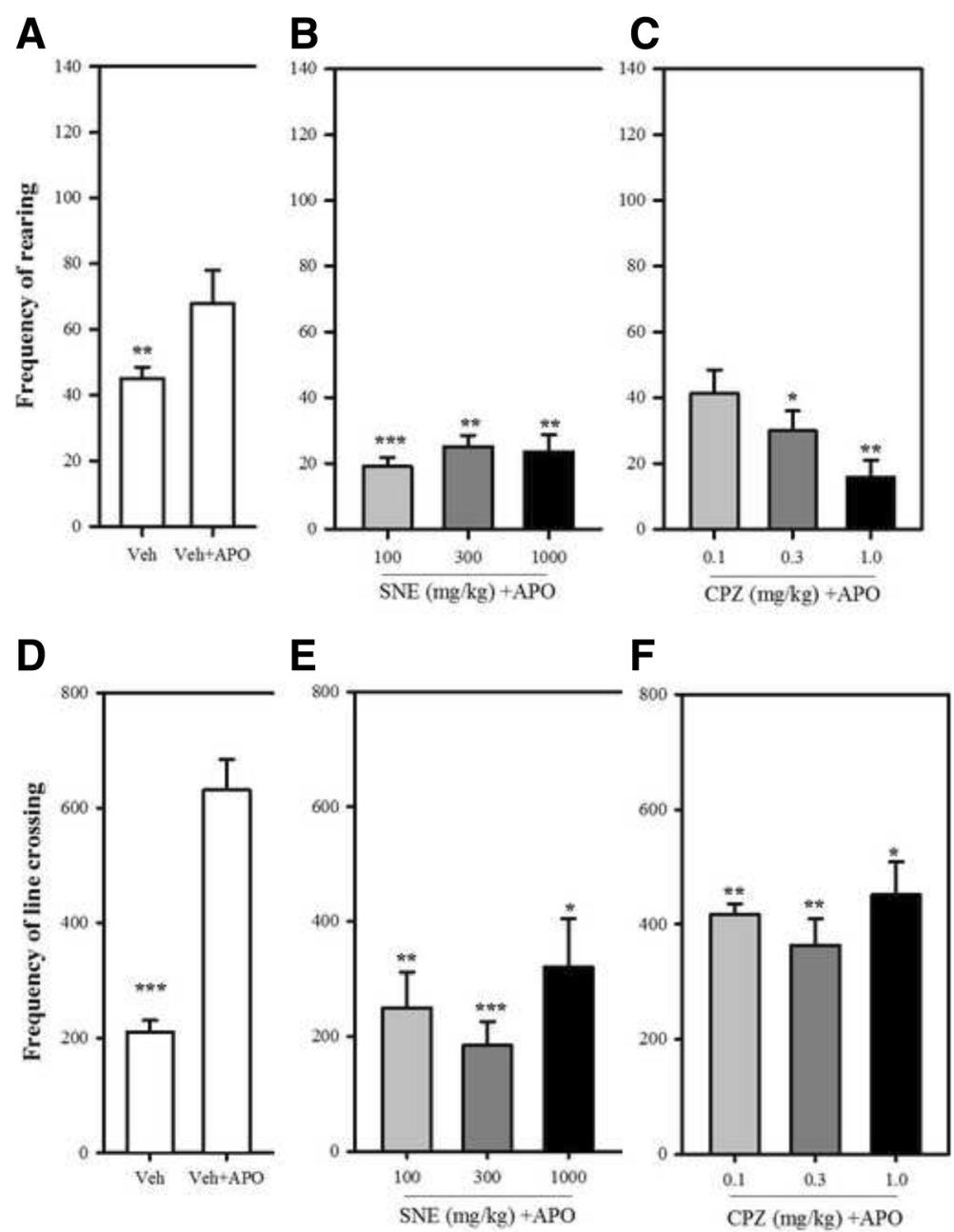

Fig. 3 Effect of SNE, CPZ and vehicle (Veh) (distilled water, $0.01 \mathrm{ml} / \mathrm{kg}, \mathrm{p} . \mathrm{O})$ on the frequency of rearing (A, B and C) and line-crossings (D, E and F) of mice, $30 \mathrm{~min}$ post apomorphine (APO) $\left(2 \mathrm{mg} / \mathrm{kg}\right.$, i.p) treatment in an open-field paradigm. Data are mean $\pm \operatorname{SEM}(n=5)$. ${ }^{*} P \leq 0.05$, ${ }^{* *}$ $P \leq 0.01,{ }^{* *} P \leq 0.001$ compared with Veh + APO group (one-way ANOVA followed by a Dunnett's multiple comparison post hoc test)

cage climbing activities in the treated mice by $7 \%, 29 \%$ and $88 \%$ respectively. Haloperidol (HAL) also exhibited similar effects on frequency of cage-climbing $\left(P<0.0001, \mathrm{~F}_{3,16}=172.10\right.$, Fig. $\left.7 \mathrm{c}\right)$ with an $84 \%, 98 \%$ and $100 \%$ decrease for the three dose levels respectively; and duration of cage-climbing $(P<0.0001$, $\mathrm{F}_{3,15}=146.70$, Fig. $7 f$ ) with an $26 \%, 100 \%$ and $100 \%$ reduction for the three dose levels respectively. $\mathrm{ED}_{50}$ values of the frequency and duration of cage-climbing showed that SNE was less potent in comparison to HAL (Table 1) in this model.

There was a significant reduction in the total frequency [\% reductions are 96\%, 98\% and 98\% for $0.1,0.3$ and $1.0 \mathrm{mg} / \mathrm{kg}$ HAL respectively] and duration [\% reductions are $60 \%, 83 \%$ and $86 \%$ for $0.1,0.3$ and $1.0 \mathrm{mg} / \mathrm{kg}$ HAL respectively] of cage climbing in the mice that received HAL $(0.1,0.3$ or $1.0 \mathrm{mg} / \mathrm{kg})+\mathrm{SNE}(100 \mathrm{mg} / \mathrm{kg})$ [(frequency: $P=0.033, \mathrm{~F}_{3,16}=3.733$; Fig. 8a), (duration: $P=0.003$,
$\mathrm{F}_{3,15}=7.136$; Fig. $\left.\left.8 \mathrm{~b}\right)\right]$. The $\mathrm{ED}_{50}(\mathrm{mg} / \mathrm{kg})$ values for the frequency and duration of cage climbing activities of haloperidol (see Fig. 9) was decreased and increased respectively when SNE $100 \mathrm{mg} / \mathrm{kg}$ (p.o) was administered with haloperidol in comparison to haloperidol alone (Table 1).

\section{Catalepsy model}

Haloperidol (0.1, 0.3 and $1 \mathrm{mg} / \mathrm{kg}$ ) exhibited a significant and dose-dependent cataleptic behaviour in the treated mice $(P=0.01$, Table 2$)$. One-way ANOVA analysis showed that SNE (100 and $1000 \mathrm{mg} / \mathrm{kg}$ ) produced a non-significant cataleptic behaviour. However, at $300 \mathrm{mg} / \mathrm{kg}$, SNE by the 60th min produced a significant (two-way ANOVA analysis, $P \leq 0.01$ ) cataleptic effect. (Table 2 ).

\section{Haloperidol-induced catalepsy}

Administration of SNE (100 mg/kg), 15 min after the administration of $\mathrm{HAL} 1.0 \mathrm{mg} / \mathrm{kg}$, completely inhibited 

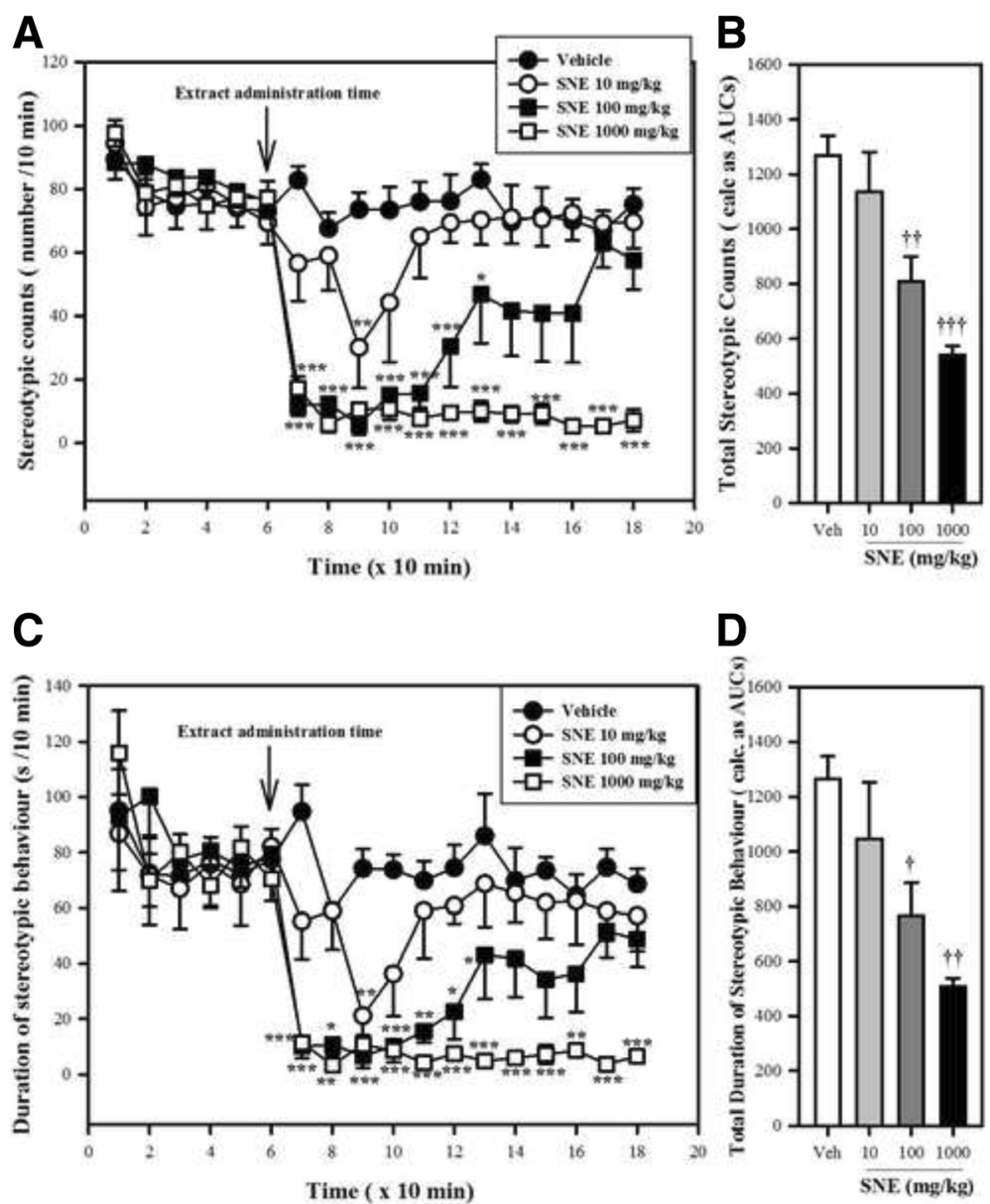

Fig. 4 Effects of SNE on the frequency $(\mathbf{A})$ and duration(C) of stereotypy in mice. Graphs $\mathbf{A}$ and $\mathbf{C}$ are the time-course effects of varying doses of SNE recorded over $180 \mathrm{~min}$. Graphs $\mathbf{B}$ and $\mathbf{D}$ indicate the total frequency and duration of stereotypy behaviour (calculated as AUCs from the time-course graphs). Data are mean $\pm \operatorname{SEM}(n=5) .{ }^{*} P \leq 0.05,{ }^{* *} P \leq 0.01,{ }^{* * *} P \leq 0.001$ compared with vehicle group (Two-way ANOVA followed by a Bonferroni's posthoc test). ${ }^{\dagger} P \leq 0.05$, ${ }^{+t} P \leq 0.01,{ }^{+t+} P \leq 0.001$ compared with vehicle group (one-way ANOVA followed by a Dunnett's multiple comparison post hoc test)

(100\%) the cataleptic effect of HAL as exhibited in the Veh + HAL group of mice. At 30 min post HAL administration, this inhibition had dropped to $39 \%$ and by the 60th min, only $9 \%$ cataleptic activity had been recorded. However, a two-way ANOVA failed to produce any significance when these events produced by SNE $100 \mathrm{mg} /$ $\mathrm{kg}$ on HAL were compared to that produced by Veh + HAL. SNE $300 \mathrm{mg} / \mathrm{kg}$ also inhibited the cataleptic effect of HAL by $4 \%$ at 15 min [not significant, $P>0.05$ ] but caused a significant $61 \%$ increase in the cataleptic behaviour at $30 \mathrm{~min}(P \leq 0.01$, two-way ANOVA followed by a Bonferroni's post hoc test; Fig. 10a). However, by the 60 th min, only an $8 \%$ increase in cataleptic behaviour was recorded. SNE $1000 \mathrm{mg} / \mathrm{kg}$ also caused an inhibition of cataleptic behaviour by $37 \%$ and $10 \%$ at 15 and 30 min post HAL treatment respectively. However, SNE $1000 \mathrm{mg} / \mathrm{kg}$ significantly increased the cataleptic event at the 60th $\min (P \leq 0.01$, two-way ANOVA followed by a Bonferroni's post hoc test; Fig. 10a). The overall assessment of effect of SNE on HAL-induced cataleptic behaviour (i.e total duration of catalepsy calculated as AUCs) suggested that cataleptic behaviour of HAL was increased by SNE 100, 300 and $1000 \mathrm{mg} / \mathrm{kg}$ by $13 \%, 61 \%$ and $52 \%$ respectively $(P=0.029$, $\mathrm{F}_{3,8}=5.11$, Fig. 10b) and this increase was significant $(P<0.05)$ only for SNE $300 \mathrm{mg} / \mathrm{kg}$.

\section{Discussion}

The findings reported in this study provide initial evidence demonstrating that SNE has antipsychotic potential when tested in murine models of schizophrenia. SNE also potentiated the antipsychotic activities of reference antipsychotic drugs; haloperidol and chlorpromazine, suggesting it may enhance the actions of current antipsychotic agents when used in combination. On the other hand, such combinations may also exacerbate the side/adverse effects associated with the use of these agents. 

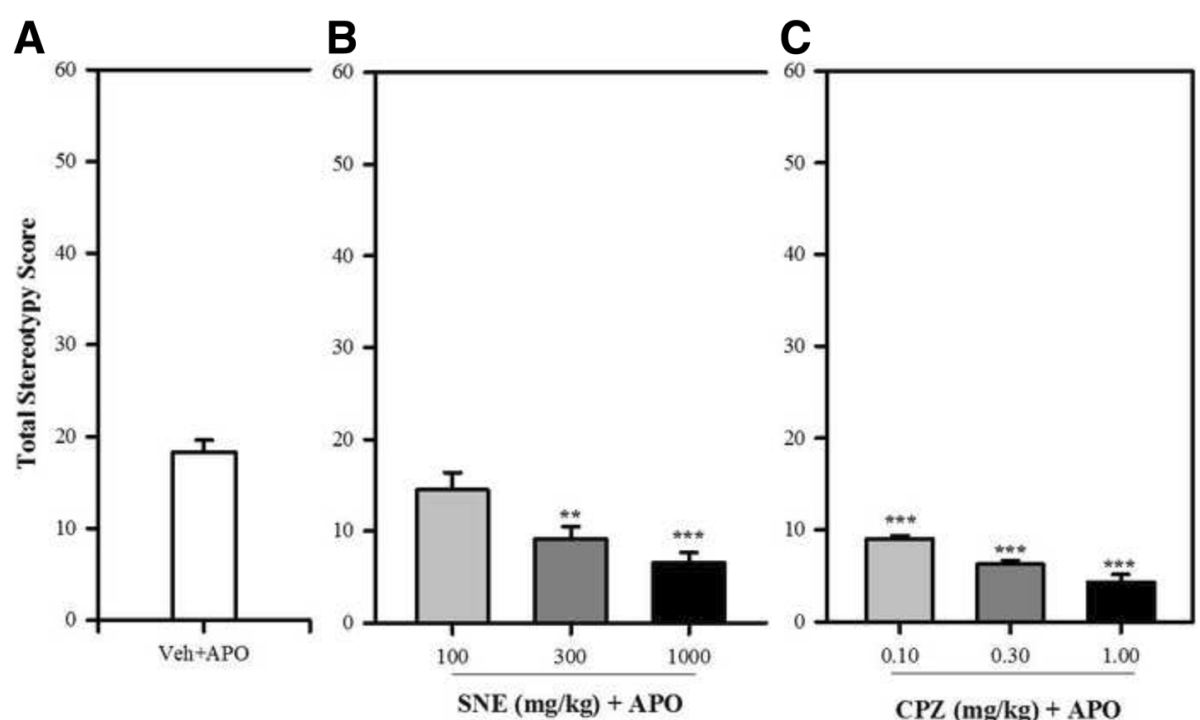

Fig. 5 Effect of SNE, CPZ and vehicle (Veh) (distilled water, $0.01 \mathrm{ml} / \mathrm{kg}$, p.o) on the stereotypy score of mice pre-treated (30 min) with apomorphine (APO) $\left(2 \mathrm{mg} / \mathrm{kg}\right.$, i.p). Data are mean $\pm \mathrm{SEM}(n=5) .{ }^{*} P \leq 0.05,{ }^{* *} P \leq 0.01,{ }^{* * *} P \leq 0.001$ compared with Veh + APO group (one-way ANOVA followed by a Dunnett's multiple comparison post hoc test)

The Irwin test primarily evaluates the qualitative effects of a test substance on the behaviour and physiological functions of experimental animals, ranging from the first doses that have observable effects up to doses that induce clear behavioural toxicity or even death [24]. The test also permits a reasonable estimate of the test substance's duration of action on the different outcome parameters [32]. In this study, the extract induced defaecation and fore-paw treading at doses 30-3000 mg/kg suggesting cholinergic and serotonergic mechanisms, respectively $[33,34]$. The sedation observed at a high dose of $3000 \mathrm{mg} / \mathrm{kg}$ also suggests GABAergic or serotonergic mechanisms [35]. Earlier reports of the neuropharmacological properties

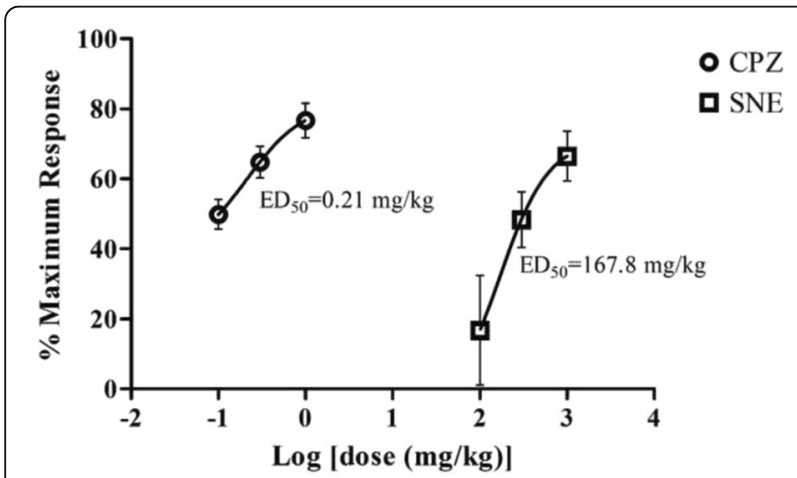

Fig. 6 A dose-response effect of SNE (100-1000 mg/kg) and CPZ (0.1-1 mg/kg) against apomorphine-induced stereotypy behaviour in mice. Data are mean $\pm \operatorname{SEM}(n=5)$ of the extract confirmed the sedative effect observed here [14].

Rearing behaviour in mice is regulated by multiple neurotransmitter systems including GABAergic $\left(\mathrm{GABA}_{\mathrm{A}}\right)$, opioidergic and dopaminergic $\left(\mathrm{D}_{2}\right)$ systems and receptors [36]. Locomotor activity in experimental animals are generally reduced by central nervous system (CNS) depressants and increased by CNS stimulants $[37,38]$. Drug-induced decrease in locomotion of experimental animals may be due to decreased motor effects and/or increased sedation [8]. We are not certain which of these two possibilities account for SNE's effect.

Stereotypy behaviour is one of the key features of psychosis and in humans, it manifests as repetitive performance of strange gestures such as asking the same questions or making the same kind of

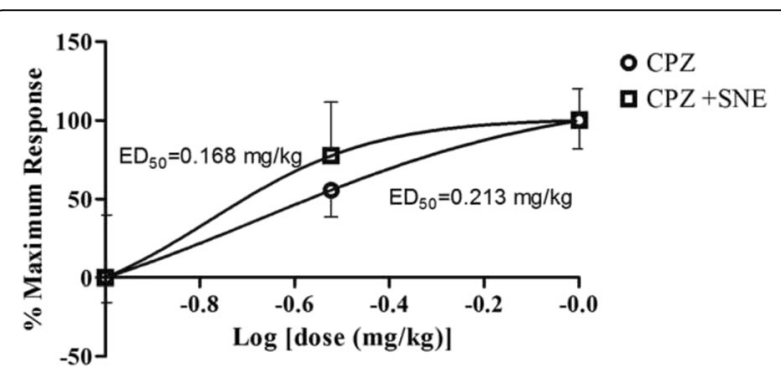

Fig. 7 A dose-response effect of CPZ (0.1-1 mg/kg) alone and CPZ $(0.1-1 \mathrm{mg} / \mathrm{kg})+$ SNE $100 \mathrm{mg} / \mathrm{kg}$ against apomorphine-induced stereotypy behaviour in mice. Data are mean \pm SEM $(n=5)$ 
Table $1 \mathrm{ED}_{50}$ values $(\mathrm{mg} / \mathrm{kg}) \pm \mathrm{SEM}$ of SNE, haloperidol $(\mathrm{HAL})$ and haloperidol (HAL) $(0.1,0.3,1.0 \mathrm{mg} / \mathrm{kg}$, i.p) + SNE (100 mg/kg, p.o) $[\mathrm{HAL}+\mathrm{SNE}]$ on the frequency and total duration of apomorphine-induced cage climbing in mice

\begin{tabular}{llll}
\hline & SNE & HAL & $H A L+$ SNE \\
\hline Frequency & $170.0 \pm 1.50$ & $0.1391 \pm 1.07$ & $0.0969 \pm 1.08$ \\
Duration & $349.1 \pm 0.03$ & $0.1047 \pm 1.61$ & $0.1439 \pm 1.70$ \\
\hline
\end{tabular}

comments [8]. The ability of SNE to reduce stereotypy count and duration is the first indication of its possible antipsychotic potential.

Apomorphine, a non-selective dopamine receptor agonist, induces changes in animal behaviour and is a test model that provides predictive validity for antipsychotic drug screening [39-42]. Administration of apomorphine in mice can produce increased locomotor activity [43], stereotyped behaviours [44], rearing/grooming [45] and cage-climbing behaviours $[46,47]$. In the present study, apomorphine was used as the agent for inducing psychotic/schizophrenic-like behaviours in mice. Psychosis has been linked with increased dopaminergic and serotonergic neurotransmissions, and both preclinical and clinical investigations have confirmed their role in the development of the disease [7, 48]. Apomorphine directly activates post-synaptic dopamine $D_{2}$ receptors in the brain, and by this mechanism low dose of apomorphine (2 $\mathrm{mg} / \mathrm{kg}$, s.c) increases locomotor activity and produce stereotypy behaviour, resulting in restricted and persevering behavioural pattern [49]. SNE blunted or reduced the apomorphine-induced rearing, locomotion, stereotypy and cage climbing suggesting that it may have antipsychotic/antischizophrenic activity.
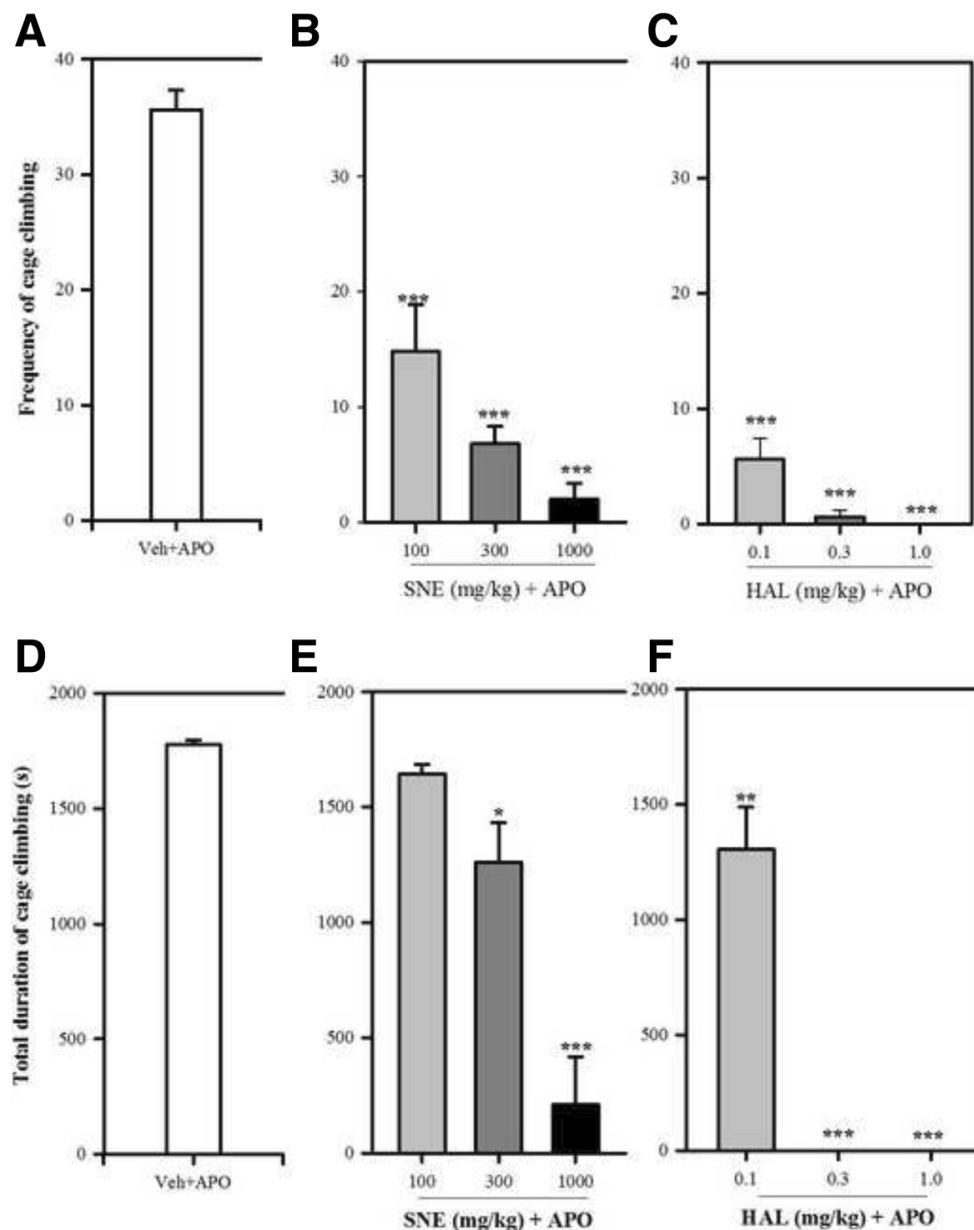

$\mathbf{F}$

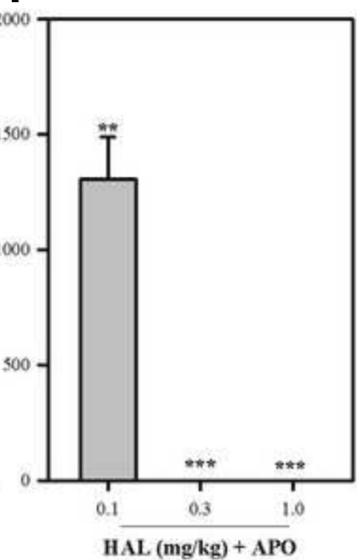

Fig. 8 Effect of SNE, HAL and vehicle (Veh) on the total frequency and duration of cage climbing of mice, 30 min post apomorphine (APO) $\left(2 \mathrm{mg} / \mathrm{kg}\right.$, i.p) treatment. Data are mean $\pm \operatorname{SEM}(n=5)$. ${ }^{*} P \leq 0.05,{ }^{* *} P \leq 0.01,{ }^{* * *} P \leq 0.001$ compared with Veh + APO group (one-way ANOVA followed by a Dunnett's multiple comparison post hoc test) 

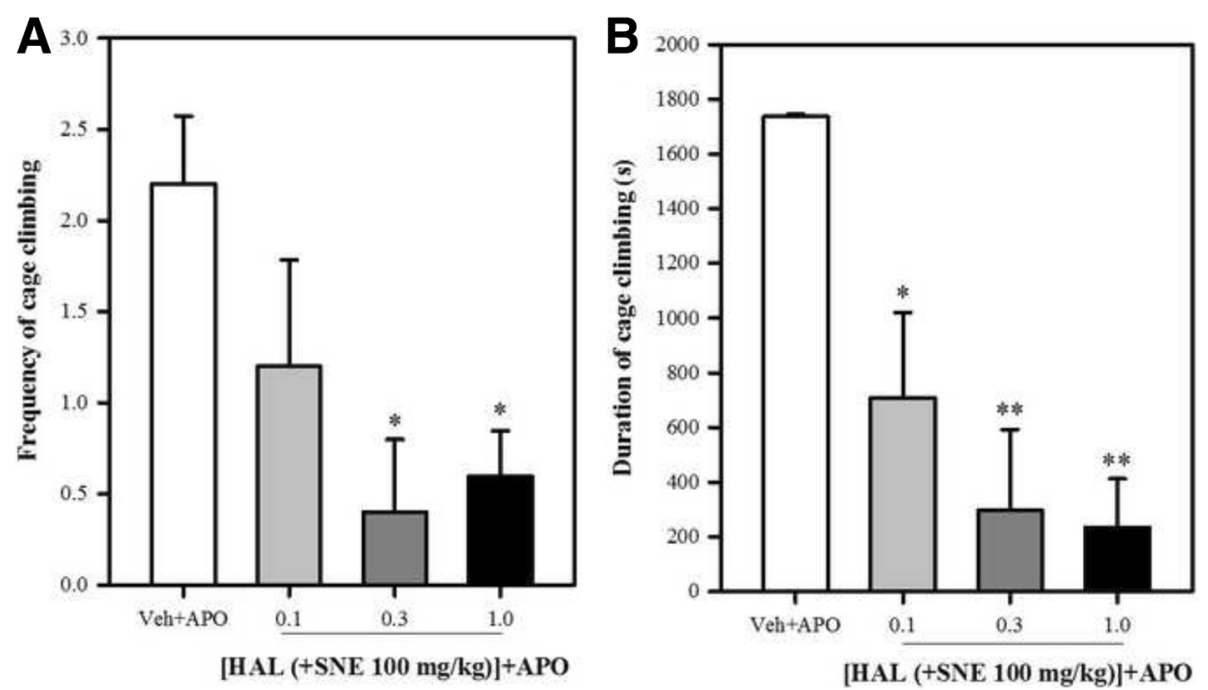

Fig. 9 Effect of haloperidol (HAL) when combined with SNE and vehicle on the total frequency (A) and duration (B) of cage climbing of mice, 30 min post apomorphine (APO) $\left(2 \mathrm{mg} / \mathrm{kg}\right.$, i.p) treatment. Data are mean $\pm \operatorname{SEM}(n=5)$. ${ }^{*} P \leq 0.05,{ }^{* *} P \leq 0.001$ compared with vehicle group (one-way ANOVA followed by a Dunnett's multiple comparison post hoc test)

Since apomorphine acts by activating dopamine receptors, it is plausible that SNE works as a dopamine receptor antagonist. However, this hypothesis would need to be tested using appropriate models e.g. receptor-binding assays.

The catalepsy test has been used to predict major tranquillizer activity as well as to evaluate motor effects of drugs, particularly related to the extrapyramidal system [29]. Catalepsy is one of the major adverse effects associated with the use of conventional antipsychotic drugs [50]. Thus, testing for cataleptic behaviour forms an integral part of the discovery and development of antipsychotic drugs. The apparent lack of cataleptic effect of SNE at $100 \mathrm{mg} / \mathrm{kg}$ in both naïve and haloperidol-treated mice suggests that the extract at lower doses may not produce any

Table 2 Effect of extracts SNE, haloperidol (HAL) and vehicle on the duration of catalepsy

\begin{tabular}{llll}
\hline $\begin{array}{l}\text { Treatment } \\
(\mathrm{mg} / \mathrm{kg})\end{array}$ & Time $(\mathrm{s})$ & \multicolumn{3}{l}{} \\
\cline { 2 - 4 } & 15th $\mathrm{min}$ & 30th $\mathrm{min}$ & 60th min \\
\hline Vehicle & $0.000 \pm 0.00$ & $0.00 \pm 0.00$ & $0.00 \pm 0.00$ \\
SNE 100 & $0.000 \pm 0.00$ & $2.038 \pm 2.04$ & $2.448 \pm 1.05$ \\
SNE 300 & $0.000 \pm 0.00$ & $2.146 \pm 2.15$ & $5.862 \pm 2.95^{* *}$ \\
SNE 1000 & $0.000 \pm 0.00$ & $0.000 \pm 0.00$ & $1.690 \pm 1.69$ \\
HAL 0.3 & $34.187 \pm 8.01$ & $87.902 \pm 33.81$ & $108.892 \pm 32.84$ \\
HAL 1.0 & $154.340 \pm 42.16^{* *}$ & $153.273 \pm 52.08^{*}$ & $125.403 \pm 55.14^{*}$ \\
HAL 3.0 & $162.660 \pm 46.41^{* *}$ & $179.510 \pm 50.24^{* *}$ & $192.122 \pm 40.87^{* *}$ \\
\hline
\end{tabular}

Data are mean \pm SEM $(n=5)$. ${ }^{*} P \leq 0.05,{ }^{* *} P \leq 0.01$, compared with vehicle group (two-way ANOVA followed by a Bonferroni's posthoc test) significant motor side-effects. This dose was also able to reduce haloperidol-induced catalepsy. The significant appearance of cataleptic event in naïve mice at $60 \mathrm{~min}$ post-SNE $300 \mathrm{mg} / \mathrm{kg}$ administration and its significant increase in haloperidol-induced catalepsy also at the 60th min may suggest that motor side effects are likely to develop with higher doses of the extract [31]. Serotonergic, cholinergic and dopaminergic $\left(D_{2}\right.$ receptor antagonism in the nigrostriatal dopaminergic pathway) systems have been implicated as mechanisms in drug-induced catalepsy or drugenhanced haloperidol-induced catalepsy [51-54]. SNE's ability to cause catalepsy does not place it in the "typical" antipsychotic category since this major side effect is shared by both "typical" and most "atypical" antipsychotic agents such as risperidone, aripiprazole, olanzapine, amisulpride, ziprasidone and sertindole [55-59]. Several clinical studies have actually indicated a less significant difference between first generation/typical and second generation/atypical antipsychotic drugs in the incidences of extrapyramidal side effects (EPS). Thus, the use of whether an antipsychotic agent induces EPS or not as the basis of classification needs re-examination [60-64]. Since the effects demonstrated here are from an extract, future isolation of active constituents of this extract responsible for the cataleptic activity would provide a much clearer understanding of SNE's mechanism of action to produce catalepsy, and hence its classification as either "typical" or "atypical". The fact that the cataleptic effect of SNE is dose-dependent and hence absent 

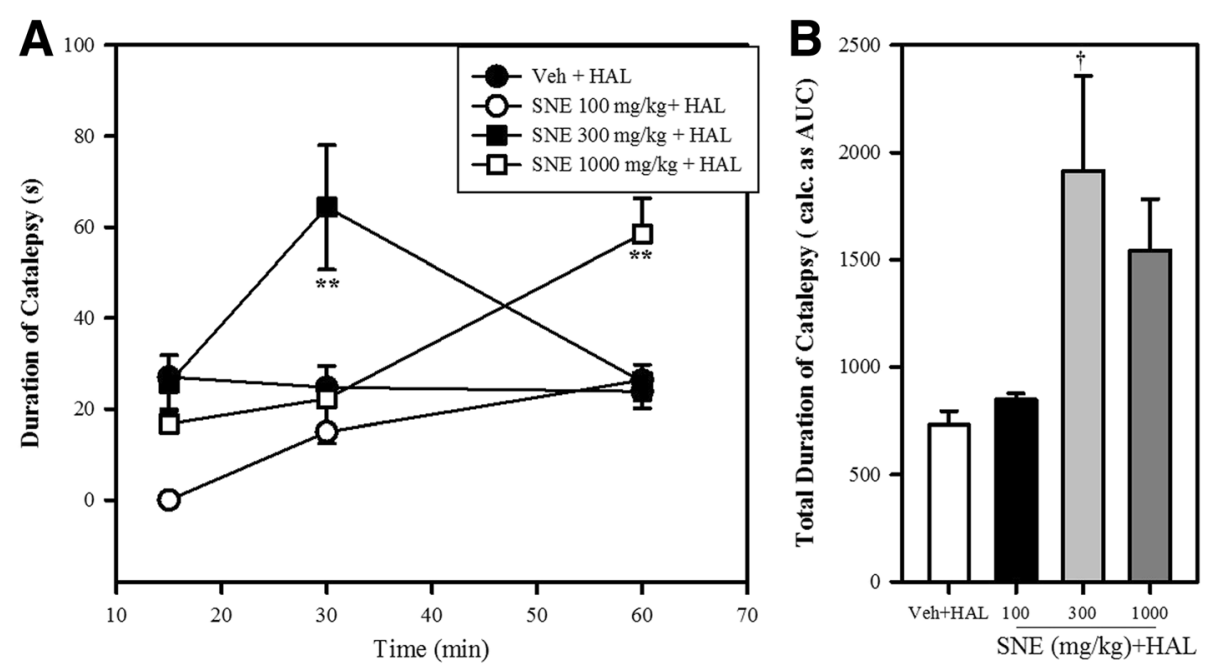

Fig. 10 Effects of SNE on haloperidol (HAL)-induced catalepsy in mice. Left paneled graph (A) is the time-course effects 15,30 and 60 min post haloperidol administration. Column graph (B) is the total duration of catalepsy (calculated as AUCs from the time-course graphs). Data are mean $\pm \operatorname{SEM}(n=5) .{ }^{* *} P \leq 0.01$ compared with vehicle group (two-way ANOVA followed by Bonferroni posthoc test). ${ }^{\dagger} P \leq 0.05$ compared with vehicle group (one-way ANOVA followed by a Dunnett's multiple comparison post hoc test)

at a low dose of $100 \mathrm{mg} / \mathrm{kg}$ of the extract is also worth mentioning.

The combination of CPZ and SNE showed potentiation of CPZ's antipsychotic-like activities in the tested models as the $\mathrm{ED}_{50}$ value of $\mathrm{CPZ}$ alone was significantly higher than the CPZ-SNE combination. Thus, SNE can potentially be used by patients on $\mathrm{CPZ}$ enabling a reduction in CPZ dose. Furthermore, SNE had a similar effect on the ED 50 of HAL when combined with it. This also suggests SNE's effects are not specific to the agent but possibly on the underlying pathophysiology, again suggesting that the extract may be used to reduce the requirement of these clinically established antipsychotic drugs in clinical settings. However, since SNE causes catalepsy (at high doses) just as much as HAL and CPZ, the doses of these orthodox drugs must be reduced if combined with SNE to prevent exaggerated extrapyramidal motor side effects while possibly enhancing the therapeutic outcome. Further clinical studies are required to determine if such combination produce a superior clinical outcomes (e.g. better control of symptoms or less side effects) than conventional therapies alone.

\section{Conclusion}

The hydro-ethanolic extract of Synedrella nodiflora whole plant possesses antipsychotic properties. This finding necessitates further investigations into the therapeutic potential and elucidation of mechanisms of action of the extract. Furthermore, chemical isolation, purification and identification of its active phyto-constituents may lead to the discovery of new molecular entities for future development as antipsychotic agents.

\section{Abbreviations \\ CPZ: chlorpromazine; HAL: haloperidol; SNE: Synedrella nodiflora extract; VEH: vehicle}

\section{Acknowledgements}

The authors acknowledge the support provided by Michael K. Clottey in the apomorphine-induced cage climbing experiments. We are also grateful to Juliet Hammond, Emmanuel Agyei-Yeboah, Mark Tetteh-Tsifoanya, Bernard Abeiku Sam, Constance Agbemelo-Tsomafo, Shirley Nyarko Adu-Poku and other technical staff at the Animal Experimentation unit of the NMIMR, Accra, Ghana and the technical staff of the Animal Resource Center, Health Sciences Center, Kuwait University Kuwait, for their immense contributions during the experiments conducted there.

\section{Funding}

The research work described in this article was financially supported by the Office of Research, Innovation and Development (ORID), University of Ghana, Accra, Ghana, grant awarded to Dr. Patrick Amoateng (reference number: URF/6/ILG-002/2012-2013). The research paper was also supported by the University of Ghana-Carnegie Next Generation of Academics in Africa Project with funding from the Carnegie Corporation of New York. Thomas K. Karikari was funded by the Biotechnology and Biological Sciences Research Council (BBSRC; http://www.bbsrc.ac.uk) grant number BB/J014532/1 through the Midlands Integrative Biosciences Training Partnership.

\section{Availability of data and materials}

The datasets analysed during the current study are available from the corresponding author on reasonable request.

\section{Authors' contributions}

PA and SA participated sufficiently in the intellectual content, conception and design of this work. PA, SA and DOS performed the experiment. PA analysed and provided interpretation to the results. PA drafted the initial manuscript and SA, DOS, KKEK, TKK, EOB and SKB edited the manuscript. All authors read and approved the final manuscript before submission. 


\section{Ethics approval}

All animal procedures and techniques used in these studies were approved by the Scientific and Technical Committee of the NMIMR [reference number STC-4 (2) 2013-14] and also by the Noguchi Institutional Animal Care and Use Committee, College of Health Sciences, University of Ghana, with protocol number NIACUC-2016-01-2Q. All procedures and techniques used were in accordance with the National Institute of Health Guidelines for the Care and Use of Laboratory Animals (NIH, Department of Health Services publication No. 83-23, revised 1985). The study protocols were approved by the Health Sciences Center Animal Research Ethics Committee, Kuwait University.

\section{Consent for publication}

Not applicable.

\section{Competing interests}

The authors declare that they have no competing interests.

\section{Publisher's Note}

Springer Nature remains neutral with regard to jurisdictional claims in published maps and institutional affiliations.

\section{Author details}

${ }^{1}$ Department of Pharmacology and Toxicology, School of Pharmacy, College of Health Sciences, University of Ghana, P.O Box LG 43, Legon, Accra, Ghana. ${ }^{2}$ Department of Animal Experimentation, Noguchi Memorial Institute for Medical Research (NMIMR), College of Health Sciences, University of Ghana, P. O. Box LG 581, Legon, Accra, Ghana. ${ }^{3}$ Department of Chemistry, School of Physical and Mathematical Sciences, College of Basic and Applied Sciences, University of Ghana, P. O. Box LG 56, Legon, Accra, Ghana. ${ }^{4}$ Department of Pharmacognosy and Herbal Medicine, School of Pharmacy, College of Health Sciences, University of Ghana, P.O Box LG 43, Legon, Accra, Ghana. ${ }^{5}$ School of Life Sciences, University of Warwick, Coventry CV4 7AL, UK. ${ }^{6}$ Midlands Integrative Biosciences Training Partnership, University of Warwick, Coventry CV4 7AL, UK. ${ }^{7}$ Department of Pharmacology and Therapeutics, Faculty of Pharmacy, Health Science Center, Kuwait University, Safat, Kuwait.

Received: 23 July 2016 Accepted: 2 August 2017

\section{Published online: 07 August 2017}

\section{References}

1. Ehmann T, Yager J, Hanson L. Early psychosis: a review of the treatment literature. Children's Mental Health Policy Research Program. 2004;7:1-52

2. Nuevo R, Chatterji S, Verdes E, Naidoo N, Arango C, Ayuso-Mateos JL. The Continuum of Psychotic Symptoms in the General Population: A Crossnational Study. Schizophrenia Bull. 2010;38:475-85.

3. Sharifi V, Eaton WW, Wu LT, Roth KB, Burchett BM, Mojtabai R. Psychotic experiences and risk of death in the general population: 24-27 year follow-up of the Epidemiologic Catchment Area study. Br J Psych. 2015;1:7

4. Harrison P. The neuropathology of schizophrenia: A critical review of the data and their interpretation. Brain. 1999;122:593-624.

5. Mullen PE. Schizophrenia and violence: from correlations to preventive strategies. Advances in PsychiatricTreatment. 2006;12:239-48.

6. Ayd FJ, Blackwell B. Discoveries in Biological Psychiatric, vol. Philadelphia: J. B. Lippincott Co.; 1970

7. Baldessarini RJ. Atypical antipsychotic drugs and the risk of sudden cardiac death. N Engl J Med. 2009;360:2136-7. author reply 2137-2138

8. Davis KL, Kahn RS. Dopamine in schizophrenia: a review and reconceptualization. Am J Psychiatry. 1991:148:1474.

9. Arana GW. An overview of side effects caused by typical antipsychotics. J Clin Psychiatry. 2000;61(Suppl 8):5-11. discussion 12-13

10. Ray WA, Chung CP, Murray KT, Hall K, Stein CM. Atypical antipsychotic drugs and the risk of sudden cardiac death. N Engl J Med. 2009;360:225-35.

11. Zhang ZJ. Therapeutic effects of herbal extracts and constituents in animal models of psychiatric disorders. Life Sci. 2004;75:1659-99.

12. Mshana NR, Abbiw DK, Addae-Mensah I, Adjanohoun E, Ahyi MRA, Enow-Orock EG, Gbile ZO, Noamesi BK, Odei MA, Adunlami H et al. Traditional Medicine and Pharmacopoeia. Contribution to the revision of ethnobotanical and floristic studies in Ghana. Scientific, Technical and Research Commission of the Organization of African Unity: Scientific, Technical and Research Commission (OAU); 2000.
13. Amoateng P, Woode E, Kombian SB. Anticonvulsant and related neuropharmacological effects of the whole plant extract of Synedrella nodiflora (L.) Gaertn (Asteraceae). J Pharm Bioall Sci. 2012;4:140-8.

14. Woode E, Amoateng P, Abotsi WMK. Ethopharmacological analysis of the effects of the whole plant extract of Synedrella nodiflora (L.) Gaertn (Asteraceae) in murine models. Der Pharmacia Sinica. 2011;2:54-67.

15. Amoateng P, Assumeng Koffuor G, Sarpong K, Oteng AK. Free Radical Scavenging and Anti-lipid Peroxidative Effects of a Hydro-ethanolic Extract of the Whole Plant of Synedrella nodiflora (L.) Gaertn (Asteraceae). Free Rad Antiox. 2011;1:70-8.

16. Amoateng P, Adjei S, Osei-Safo D, Ameyaw EO, Ahedor B, N'Guessan BB, Nyarko AK. A hydro-ethanolic extract of Synedrella nodiflora (L.) Gaertn ameliorates hyperalgesia and allodynia in vincristine-induced neuropathic pain in rats. J Basic Clin Physiol Pharmacol. 2015;26:383-94.

17. Woode E, Amoateng P, Ansah C, Duwiejua M. Anti-Nociceptive Effects of an Ethanolic Extract of the Whole Plant of Synedrella nodiflora (L.) Gaertn in Mice: Involvement of Adenosinergic Mechanisms. J Pharmacol Toxicol. 2009;4:17-29.

18. Adjei S, Amoateng P, Osei-Safo D, Ahedor B, N'quessan BB, Addo P, Asiedu-Gyekye IJ. Biochemical and haematological changes following an acute toxicity study of a hydro-ethanolic whole plant extract of Synedrella nodiflora $(\mathrm{L})$ Gaertn in male Sprague-Dawley rats. J Med Biomed Sci. 2014;3:31-7.

19. Adjei S, Amoateng P, Osei-Safo D, Sasu C, N'guessan BB, Addo P, Asiedu-Gyekye IJ. Sub-acute toxicity of a hydro-ethanolic whole plant extract of Synedrella nodiflora $(\mathrm{L})$ Gaertn in rats. Int J Green Pharm. 2014;8:271-5.

20. Amoateng P, Adjei S, Osei-Safo D, Ahedor B, Mahmood SA, N'guessan BB, Asiedu-Gyekye IJ, Nyarko AK. Long-term continuous administration of a hydro-ethanolic extract of Synedrella nodiflora (L) Gaertn in male SpragueDawley rats: biochemical, haematological and histopathological changes. Ghana Med J. 2016;50:163-71.

21. Amoateng P. Neuropharmacological effects of Synedrella nodiflora: Anticonvulsant and related effects of a hydro-ethanolic whole plant extract of Synedrella nodiflora (L.) Gaertn: LAP Lambert Academic Publishing; Saarbrücken, Germany, 2011. p. 120-1.

22. Amoateng P, Adjei S, Osei-Safo D, Kukuia KKE, Kretchy IA, Sarkodie JA, N'Guessan BB: Analgesic effects of a hydro-ethanolic whole plant extract of Synedrella nodiflora (L.) Gaertn in paclitaxel-induced neuropathic pain in rats. BMC Res Notes. 2017;10:226.

23. Evans WC. Trease and Evans' Pharmacognosy. 15th ed. Saunders Ltd: Edinburgh; 2002.

24. Irwin S. Comprehensive observational assessment. Asystematic,quantitative procedure for assessing the behavioural and physiologic state of the mouse. Psychoparmacologia. 1968;13:222-56.

25. Kenneth SK, Kenneth ID. Genetic control of apomorphine induced climbing behaviour in two inbred mouse strains. Brain Res. 1984;293:343-51.

26. Amos S, Abbah J, Chindo B, Edmond I, Binda L, Adzu B, Buhari S, Odutola AA, Wambebe C, Gamaniel K. Neuropharmacological effects of the aqueous extract of Nauclea latifolia root bark in rats and mice. J Ethnopharmacol. 2005;97:53-7.

27. Fivelman Q, Adagu I, Warhurst D. Modified fixed-ratio isobologram method for in vitro interaction between atovaquone and proguanil or dihydroartemisinin against drug resistant strain of Plasmodium falciparum. Antimicrob Agents Chemother. 2004;48:4097-102.

28. Davis AS, Jenner $P$, Marsden CD. A comparison of motor behaviours in groups of rats distinguished by their climbing response to apomorphine. $\mathrm{Br}$ J Pharmacol. 1986;87:129-37.

29. Sanberg PR, Bunsey MD, Giordano M, Norman AB. The catalepsy test: its ups and downs. Behav Neurosci. 1988;102:748.

30. Taïwe GS, Bum EN, Talla E, Dawe A, Moto FCO, Ngoupaye GT, Sidiki N, Dabole B, Dzeufiet PDD, Dimo T. Antipsychotic and sedative effects of the leaf extract of Crassocephalum bauchiense (Hutch.) Milne-Redh (Asteraceae) in rodents. J Ethnopharmacol. 2012;143:213-20.

31. Pemminati S, Nair V, Dorababu P, Gopalakrishna H, Pai M. Effect of ethanolic leaf extract of Ocimum sanctum on haloperidol-induced catalepsy in albino mice. Indian J Pharmacol. 2007:39:87.

32. Porsolt RD, Castagné $V$, Dürmüller $N$, Lemaire $M$, Moser $P$, Roux S, France $C P$. Central Nervous System (CNS) Safety Pharmacology Studies. In: Vogel HG, editor. Drug discovery and evaluation: safety and pharmacokinetic assays. Germany: Springer-Verlag; 2006. p. 18. 
33. Arnt J, Hyttel J. Facilitation of 8-OHDPAT-induced forepaw treading of rats by the 5-HT 2 agonist DOI. Eur J Pharmacol. 1989;161:45-51.

34. Rang R, Dale M, Ritter J, Flower R, Henderson G. Chapter 13: Cholinergic transmission. In: Rang \& Dale's Pharmacology. 7th ed. Edinburgh: Elsevier Churchill Livingstone; 2012. p. 158.

35. Trevor A, Way W. Sedative-Hypnotics. In: Basic and Clinical Pharmacology. Katzung B, Masters S, Trevor A, 12. USA: McGraw-Hill Lange; 2012: 373-386.

36. Walting KJ. Overview of central nervous system receptors. In: Walting KJ, editor. The RBI Handbook of Receptor Clarification and signal Transduction. MA: RBI, Natick; 1998. p. 2-45.

37. Nesa L, Munira S, Mollika S, Islam M, Choin H, Chouduri AU, Naher N. Evaluation of analgesic, anti-inflammatory and CNS depressant activities of methanolic extract of Lawsonia inermis barks in mice. Avicenna J Phytomed. 2014;4:287-96.

38. Zaman A, Khan MSS, Akter L, Syeed SH, Akter J, Al Mamun A, Alam ME, Habib MA, Jalil MA. Exploring new pharmacology and toxicological screening and safety evaluation of one widely used formulation of Nidrakar Bati from South Asia region. BMC Complement Altern Med. 2015;15:121.

39. Gobira PH, Ropke J, Aguiar DC, Crippa JAS, Moreira FA. Animal models for predicting the efficacy and side effects of antipsychotic drugs. Rev Bras Psiquiatr. 2013;35:S132-9.

40. Jones CA, Watson DJG, Fone KCF. Animal models of schizophrenia. Br J Pharmacol. 2011;164:1162-94.

41. Lipska BK, Weinberger DR. To Model a Psychiatric Disorder in Animals: Schizophrenia As a Reality Test. Neuropsychopharmacology. 2000;23:223-39.

42. Weiner I, Gaisler I, Schiller D, Green A, Zuckerman L, Joel D. Screening of antipsychotic drugs in animal models. Drug Dev Res. 2000;50:235-49.

43. Matsumoto K, Cai B, Ohta H, Imamura L, Watanabe H. Apparent enhancement by SCH 23390 of apomorphine-induced locomotor activity in mice. Pharmacol Biochem Behav. 1991:39:699-703.

44. Battisti JJ, Uretsky NJ, Wallace $\amalg$. Sensitization of apomorphine-induced stereotyped behavior in mice is context dependent. Psychopharmacology. 1999;146:42-8

45. Matsumoto K, Bing C, Sasaki K, Watanabe H. Methamphetamine-and apomorphine-induced changes in spontaneous motor activity using a new system to detect and analyze motor activity in mice. J Pharmacol Methods. 1990;24:111-9.

46. Marcais H, Protais P, Costentin J, Schwartz J. A gradual score to evaluate the climbing behaviour elicited by apomorphine in mice. Psychopharmacology. 1978:56:233-4

47. Wilcox RE, Smith RV, Anderson JA, Riffee WH. Apomorphine-induced stereotypic cage climbing in mice as a model for studying changes in dopamine receptor sensitivity. Pharmacol Biochem Behav. 1980;12:29-33.

48. Szechtman H. Behavior performed at onset of drug action and apomorphine stereotypy. Eur J Pharmacol. 1986;121:49-56.

49. Stolk JM, Rech RH. Antagonism of O-amphetamine by methylp-tyrosin Behavioural evidence for participation of cathelcolamine stores and synthesis in the amphetamine stimulant response. Neuropharmacology. 1970;9:249-63.

50. Shopsin B, Klein H, Aaronsom M, Collora M. Clozapine, chlorpromazine, and placebo in newly hospitalized, acutely schizophrenic patients: a controlled, double-blind comparison. Arch Gen Psych. 1979;36:657-64.

51. Klemm W. Evidence for a cholinergic role in haloperidol-induced catalepsy. Psychopharmacology. 1985;85:139-42.

52. Neal-Beliveau BS, Joyce JN, Lucki I. Serotonergic involvement in haloperidolinduced catalepsy. J Pharmacol Exp Ther. 1993;265:207-17.

53. Surmeier DJ, Ding J, Day M, Wang Z, Shen W. D1 and D2 dopaminereceptor modulation of striatal glutamatergic signaling in striatal medium spiny neurons. Trends Neurosci. 2007;30:228-35.

54. Wadenberg M-L. Serotonergic mechanisms in neuroleptic-induced catalepsy in the rat. Neurosci Biobehav Rev. 1996;20:325-39.

55. Komossa K, Rummel-Kluge C, Schwarz S, Schmid F, Hunger H, Kissling W, Leucht S. Risperidone versus other atypical antipsychotics for schizophrenia. Cochrane Database Sys Rev. 2011:CD006626.

56. Praharaj SK, Jana AK, Sarkhel S, Sinha VK. Acute dystonia, akathisia, and parkinsonism induced by ziprasidone. Am J Ther. 2014:21:38-40.

57. Chen MH, Liou YJ. Aripiprazole-associated acute dystonia, akathisia, and parkinsonism in a patient with bipolar I disorder. J Clin Psychopharmacol. 2013;33:269-70.

58. Zoccali RA, Bruno A, Muscatello MR. Efficacy and safety of sertindole in schizophrenia: a clinical review. J Clin Psychopharmacol. 2015;35:286-95.
59. Mandal N, Singh OP, Sen S. Extrapyramidal side effects with low doses of amisulpride. Indian J Psych. 2014;56:197-9.

60. Rummel-Kluge C, Komossa K, Schwarz S, Hunger H, Schmid F, Kissling W, Davis JM, Leucht S. Second-generation antipsychotic drugs and extrapyramidal side effects: a systematic review and meta-analysis of headto-head comparisons. Schizophr Bull. 2012;38:167-77.

61. Leucht S, Corves C, Arbter D, Engel RR, Li C, Davis JM. Second-generation versus first-generation antipsychotic drugs for schizophrenia: a metaanalysis. Lancet. 2009;373:31-41.

62. Leucht S, Cipriani A, Spineli L, Mavridis D, Orey D, Richter F, Samara M, Barbui C, Engel RR, Geddes JR, et al. Comparative efficacy and tolerability of 15 antipsychotic drugs in schizophrenia: a multiple-treatments metaanalysis. Lancet. 2013;382:951-62.

63. Grunder G, Hippius H, Carlsson A. The 'atypicality' of antipsychotics: a concept re-examined and re-defined. Nature Rev Drug Discov. 2009:8:197-202.

64. Jindal RD, Keshavan MS. Classifying antipsychotic agents : need for new terminology. CNS Drugs. 2008:22:1047-59.

\section{Submit your next manuscript to BioMed Central and we will help you at every step:}

- We accept pre-submission inquiries

- Our selector tool helps you to find the most relevant journal

- We provide round the clock customer support

- Convenient online submission

- Thorough peer review

- Inclusion in PubMed and all major indexing services

- Maximum visibility for your research

Submit your manuscript at www.biomedcentral.com/submit
) Biomed Central 